\title{
Augustine's baptism: Its significance once and today
}

\begin{tabular}{|c|c|}
\hline \multicolumn{2}{|c|}{$\begin{array}{l}\text { Author: } \\
\text { Johannes van Oort }{ }^{1,2}\end{array}$} \\
\hline $\begin{array}{l}\text { Affiliations: } \\
{ }^{1} \text { Early Christian } \\
\text { Patristics, Radk } \\
\text { University, the }\end{array}$ & $\begin{array}{l}\text { hity and } \\
\text { boud } \\
\text { Netherlands }\end{array}$ \\
\hline $\begin{array}{l}{ }^{2} \text { Department } 0 \\
\text { History and } \mathrm{Ch} \\
\text { University of } \mathrm{P} \\
\text { South Africa }\end{array}$ & $\begin{array}{l}\text { f Church } \\
\text { urch Polity, } \\
\text { retoria, }\end{array}$ \\
\hline $\begin{array}{l}\text { Note: } \\
\text { Opening addre } \\
\text { South African } \\
\text { on Augustine o } \\
\text { 'Augustine and } \\
\text { Christianity', U } \\
\text { Pretoria, 24-2 } \\
\text { Prof. Dr Hans } \\
\text { Professor Extra } \\
\text { the Departmer } \\
\text { History and Po } \\
\text { Faculty of The } \\
\text { the University } \\
\text { Pretoria, South }\end{array}$ & $\begin{array}{l}\text { Sys at the First } \\
\text { Symposium } \\
\text { of Hippo: } \\
\text { Manichaean } \\
\text { Iniversity of } \\
6 \text { April } 2012 . \\
\text { van Oort is } \\
\text { aordinarius in } \\
\text { nt of Church } \\
\text { lity of the } \\
\text { ology at } \\
\text { of Pretoria, } \\
h \text { Africa. }\end{array}$ \\
\hline $\begin{array}{l}\text { Corresponden } \\
\text { Johannes van }\end{array}$ & $\begin{array}{l}\text { Ice to: } \\
\text { Oort }\end{array}$ \\
\hline $\begin{array}{l}\text { Email: } \\
\text { j.van.oort@pla }\end{array}$ & anet.nl \\
\hline $\begin{array}{l}\text { Postal address } \\
\text { Van Renessela } \\
\text { AH Zeist, the N }\end{array}$ & $\begin{array}{l}\text { an 24, } 3703 \\
\text { Jetherlands }\end{array}$ \\
\hline $\begin{array}{l}\text { Dates: } \\
\text { Received: } 20 \mathrm{D} \\
\text { Accepted: } 10 \mathrm{~J} \\
\text { Published: } 10\end{array}$ & $\begin{array}{l}\text { ec. } 2012 \\
\text { lan. } 2013 \\
\text { Apr. } 2013\end{array}$ \\
\hline $\begin{array}{l}\text { How to cite th } \\
\text { Van Oort, J., } 2 \\
\text { 'Augustine's ba } \\
\text { significance on } \\
\text { HTS Teologiese } \\
\text { Theological Stc } \\
\text { Art. \#1914, } 3 \text { p } \\
\text { dx.doi.org/10. } \\
\text { v69i1.1914 }\end{array}$ & $\begin{array}{l}\text { is article: } \\
013, \\
\text { aptism: Its } \\
\text { nce and today', } \\
\text { Studies/ } \\
\text { udies 69(1), } \\
\text { oages. http:// } \\
\text { 4102/hts. }\end{array}$ \\
\hline $\begin{array}{l}\text { Copyright: } \\
\text { (C) 2013. The A } \\
\text { Licensee: AOSI } \\
\text { OpenJournals. } \\
\text { is licensed und } \\
\text { Creative Comn } \\
\text { Attribution Lic }\end{array}$ & $\begin{array}{l}\text { uthors. } \\
\text { IS } \\
\text { This work } \\
\text { ler the } \\
\text { nons } \\
\text { ense. }\end{array}$ \\
\hline Read online: & $\begin{array}{l}\text { Scan this QR } \\
\text { code with your } \\
\text { smart phone or } \\
\text { mobile device } \\
\text { to read online. }\end{array}$ \\
\hline
\end{tabular}

The article describes in broad outline Augustine's baptism in Milan (386) and stresses its significance for Augustine's transition from Manichaean Christianity to Nicene Catholic Christianity.

This very night it will be 1625 years ago that the future Church father Augustine from Hippo in North Africa was baptised in the North Italian city of Milan by its Nicene Christian bishop Ambrose.

In those days Christian baptism was an extensive ceremony. ${ }^{1}$ Its preparations started weeks before the actual baptism took place. A person who would like to receive baptism should first 'turn in his name' (the so-called nomen dare) to be inscribed by the Church official, who as a rule, was the bishop. ${ }^{2}$ After that he ${ }^{3}$ received an extensive catechetical instruction. Baptism took place at dawn on Easter Sunday. We do not know the exact rites of the Church of Milan at the time of Augustine, but from two works by Ambrose, his so-called On the Sacraments (De sacramentis) and On the Mysteries (De mysteriis) we seem to be able to reconstruct how baptism was administered in 387. It was accompanied by rites such as a washing of feet (symbolising the forgiveness of sins, a symbol dear to Ambrose), anointments, the laying on of hands, and so on. Also, the newly baptised person received the sign of the cross on the forehead: from then onwards he belonged to Christ. This sign was originally an X, derived from the old-Hebrew sign of Tau already mentioned by the prophet Ezekiel (ch. 9), and also in St John's Apocalypse (cf. e.g. Daniélou 1964:154f., 330f.). This sign was considered a mark of property and protection.

Augustine's baptism took place in the baptistery of Milan's main church. A couple of years ago, when excavations were conducted for the construction of an underground, the ancient baptistery from Ambrose's times was discovered. ${ }^{4}$ When visiting present-day Milano, you can still see it: after entering the cathedral at the back, left side, you should immediately turn to the right and then go downstairs. I mention this, because only few persons visiting the immense cathedral of Sta. Thecla are aware of this possibility. When seeing the ancient baptistery, you may learn how the adult Augustine, by then 32 years old, was immersed in 'living' (that is: flowing) water. This immersion took place three times, after he had heard three questions: 'Do you believe in God the Almighty Father?'; 'Do you believe in our Lord Jesus Christ and his cross?'; 'Do you also believe in the Holy Spirit?' and after that he subsequently answered three times: 'Credo, I believe!' (Ambrosius De sacramentis 2, 20; cf. Ambrosius De mysteriis 21; 28). It is from the baptismal rite with its three questions and answers that we still have our tripartite confessions (see e.g. Kelly 1960:30-61, esp. pp. 36-37 on Ambrose).

Who was the person then baptised? Many popular tales (and even handbooks of history, philosophy and theology!) still have it that a certain pagan, after a dramatic conversion, became a Christian. This representation is wrong. What really happened was this: an ambitious young man from Africa - for a few years already even the most important professor of rhetoric of the whole Roman Empire, the man who delivered speeches for the Emperor and a consul ${ }^{5}$ - had resigned from his position and received baptism in the Catholic Church. Originally, in North Africa, he was raised in some sort of Catholic environment; as a student he became a member of a gnosticChristian Church and stayed with its adherents for at least ten years; for a short time he was a sceptic; and by now he had become a Catholic Christian. The change was not from paganism to Christianity, but from one form of Christianity to another.

\footnotetext{
The following lines provide a very brief overview. The best recent book on early Christian baptism is the extensive study by Ferguson (2009). Also important is the rather brief overview by Jensen (2012), as well as her specialist study (2011). In my presentation I mainly focus on the rites as they may be reconstructed from Ambrose's works (see below).
}

2.See, for example, Ferguson (2009), with reference to Cyril of Jerusalem's Procatechesis 1 and 4.

3.As a matter of fact, women were baptised as well. When simply speaking of 'he', I follow the ancient rites' inclusive language.

4.This baptistery was discovered and excavated by the archaeologist Roberti in the 1960s. See, for example, Roberti and Paredi (1974)

5.Augustinus, Confessionum libri XIII VI, 6, 9; Augustinus, Contra litteras Petiliani III, 25, 30. Cf. Courcelle ([1950] 1968:79-83). 
It is only recently, based on a number of important discoveries, that we have become aware of this fact. Augustine made a dramatic change from 'gnostic' Christianity to so-called Nicene (orthodox) Christianity. And this will be the very essence of our conference: examining this change and studying the still most hidden period of Augustine's life, the time from his 18th until at least his 28th year, the years when he was an adherent of the gnostic-Christian Church of the Manichaeans. It is our aim to ask what this meant for his theology, philosophy, spirituality, church polity, in brief: for his whole life and thought.

It is curious that Augustine himself always stated that he had been a Manichaean for nine years, although it is crystal clear from his writings that the period lasted for at least ten years (cf. e.g. Courcelle 1954:81-85). This may be due to his rhetoric: nine is an imperfect number and thus, looking back, Augustine considered the Manichaean period of his life as being imperfect (Ferrari 1975:210-216). But he spoke of nine years. Rather recently a famous Roman Catholic Augustine specialist still tried to play down the duration of his Manichaean period by speaking not of nine years, but of nine months! (Studer 1993:167). Besides, the present pope Benedictus, an ardent student of Augustine, in his previous capacity as the scholar Joseph Ratzinger, once stated that Augustine, during the period before his baptism (i.e. as a Manichaean) was not really interested in religious matters, and he also spoke of a 'vorchristliche' [pre-Christian] Augustine, that is to say an Augustine who only became a Christian at the time of his conversion and baptism in 386 and 387 ([1965] 1967:217-222, esp. 222).

Through Augustine's own writings, however, we are instructed otherwise. Nowhere does he hide his early search for truth and Christian spirituality and he clearly states that this search started very early in his life and, moreover, that it was fully continued, and even intensified, when he was an adherent of Manichaeism. ${ }^{6}$ Recent discoveries make us understand this fact. New texts from the Dakleh Oasis, some $800 \mathrm{~km}$ SSW from Cairo in the Egyptian-Libyan desert, testify to the essential Christian character of Manichaeism. ${ }^{7}$ We are proud, that researchers from Australia who work on these texts have joined us here and that they are going to compare these new findings with Augustine's testimonies. Also, from a pivotal find such as the Mani Codex - a very small booklet with very thin leather pages of only $3.5 \mathrm{~cm}$ by $4.5 \mathrm{~cm}$ (a photo of one double page is on the conference programme) - we learn that Mani, the prophet from present-day Iraq who lived in the third century (216-276), was raised in a JewishChristian community and considered himself to be an apostle of Jesus Christ. ${ }^{8}$

6.One may, first of all, read the Confessions from the first lines onwards. In Book III, $3,6,10$, in the narrative of his making acquaintance with Manichaeism, it runs: ' $O$ truth, truth, how inwardly even then did the marrow of my soul sigh after you.'

7.Some main publications: Gardner (1996, 2007); Gardner, Alcock and Funk (1999). See also Gardner and Lieu (2004) for key texts from Kellis in English translation.

8.See the main publications of the original text (with German translation): Henrichs and Koenen (1970:97-216); Koenen and Römer (1988); Römer (1994). There are also English translations of the main fragments in Gardner and Lieu (2004).
It is not feasible to give a full description of Mani or Manichaios or Mānī hajjā [the living Mani] here. Those interested in the main particulars of his life and message may read a rather recent article published in the University of Pretoria's journal Verbum et Ecclesia (Van Oort 2009b). Manichaeism, the religion or church (ekklēsia) established by Mani, turned out to be - in any case in Roman North Africa, such as for instance in Italy, Palestine or Egypt - a deviant form of Christianity. It also fully belonged to the currents which still are commonly termed as 'Gnosticism'. Christian Gnostics like the Manichaeans stressed the importance of inner knowledge or gnōsis. Augustine, in his decade-long search for truth and the self, did the same.

Or should we say: Augustine continued to do the same, also after his conversion to Nicene Christianity? Personally I'm inclined to say that he learned a lot from the Manichaeans' Christ-centred spirituality (see Van Oort 2002). And, curiously, although he later considered them to be dangerous heretics, he once explicitly stated: 'Thus what I had learned among them that is true, I hold ....'. ${ }^{9}$ By and then deviant Christians may testify to certain aspects of the truth which other Christians forgot.

When asked about the relevance of our conference for today, my answer would be along these lines. We may learn from both Augustine and the Manichaeans because of their living, Christ-centred spirituality. And in order to understand Augustine and his immense influence on the mainstream forms of Christianity such as Roman Catholicism, Anglicanism and most varieties of Protestantism, we should also see that this spirituality centred on the human inner self. It was personal spirituality and Augustine kept this as a characteristic of his theology. So, for Christians who know their inspiring sources, it is not necessary to go to India or the Far East, in order to discover the inner self. This discovery was part and parcel of the Christian tradition, and Augustine in particular may be our guide. His stress on 'Call' and 'Answer', his emphasis on the importance of the preached Word as being an address liberating humans - an essential point of view which became so important with Augustineinspired Reformers like Luther and Calvin (see e.g. Van Oort 2009a) - may be seen as instigated by this 'gnostic' past as well.

Furthermore, here in Africa we may be extra aware of the fact that he was an African. In the age-long tradition of Christian iconography, we usually find Augustine depicted as some sort of white European bishop. ${ }^{10}$ But, in all probability, this is a severe mistake. The oldest representation of Augustine we have, namely a fresco in the Lateran library in Rome, dates from about circa $600 .{ }^{11}$ One may still see some African characteristics when looking at this fresco. But there is more. His mother's name is Monnica, with double ' $n$ ', and without

9.De utilitate credendi 36: "Ita quod apud eos [sc. Manichaeos] uerum didiceram, teneo ....'

10.For example, Courcelle and Courcelle (1965), and the subsequent volumes in a whole series.

11.See, for example, Wilpert (1931:1-3) (+ full-colour plate). As a matter of fact, the fresco has been duplicated in many other publications until the present day. 
a doubt this is a so-called theophoric name, that is a name in which a godhead is mentioned: in this case the name of Mon, a Berber deity (e.g. Frend 1942:188-191; cf. Frend 1951: esp. 230). Thus, in all likelihood, it was (at least) through his mother that Augustine descended from Africa's indigenous people, the Berbers. He also says himself that he is an African for the Africans (Afer pro Afris) (Epistula 17,1) and he tells that, when overseas in Italy, his accent betrayed him (De ordine II, $17,45)$. And, last but not least, we have the testimony of the Italian Catholic bishop Julian of Eclanum who, at the end of Augustine's life, accused him of still being a Manichaean: 'if a leopard could change his spots and an 'Aethiops' (a Black person) his skin, only then it would be possible for you to cleanse yourself from the mysteries of the Manichaeans. ${ }^{\prime 2}$

There seems to be even a double amount of truth in this venomous remark. During the next two days, we'll particularly look at the Manichaean 'spots' of the greatest African ever.

\section{Acknowledgements Competing interests}

The author declares that he has no financial or personal relationship(s) which may have inappropriately influenced him in writing this article.

\section{References}

Ambrosius, 1950a, 'De mysteriis', in B. Botte (ed.), Des sacrements; Des mystères. Texte établi et annoté par Dom Bernard Botte, pp. 1-139, Cerf, Paris. (Sources chrétiennes 25)

Ambrosius, 1950b, 'De sacramentis', in B. Botte (ed.), Des sacrements; Des mystères. Texte établi et annoté par Dom Bernard Botte, pp. 1-139, Cerf, Paris. (Sources chrétiennes 25).

Ambrosius, 1990a, 'De mysteriis', in J. Schmitz, De sacramentis; De mysteriis. Über die Sakramente; Über die Mysterien. Übersetzt und eingeleitet von Josef Schmitz, pp. 1-279, Herder, Freiburg. (Fontes Christiani 3).

Ambrosius, 1990b, 'De sacramentis', in J. Schmitz, De sacramentis; De mysteriis. Über die Sakramente; Über die Mysterien. Übersetzt und eingeleitet von Josef Schmitz, pp. 1-279, Herder, Freiburg. (Fontes Christiani 3).

Augustinus, 1891, 'De utilitate credendi', in J. Zycha, Sancti Aureli Augustini De utilitate credendi, pp. 1-797, Tempsky, Vindobonae (Vienna).

Augustinus, 1909, 'Contra litteras Petiliani', in M. Petschenig (ed.), Contra litteras Petiliani libri tres, pp. I-XV+1-600, Tempsky, Vindobonae (Vienna).

Augustinus, 1922, 'De ordine', in P. Knöll (ed.), Sancti Aureli Augustini Contra Academicos, De beata vita, De ordine, pp. 1-219, Tempsky, Vindobonae (Vienna).

12.Contra secundam Juliani responsionem imperfectum opus IV, 42 (citing Jr 13:23).
Augustinus, 1926, 'Confessionum libri XIII', in P. Knöll (ed.), S. Avreli Avgvstini Confessionvm libri tredecim, pp. 1-348, Teubner, Leipzig.

Augustinus, 2004, 'Contra secundam Juliani responsionem imperfectum opus', in M. Zelzer (ed.), Contra secundam Juliani responsionem imperfectum opus, Tomus II, Libri IV-VI, pp. 1-506, Österreichische Akademie der Wissenschaften, Wien.

Courcelle, P., 1954, 'Saint Augustin manichéen à Milan?', Orphéus 1, 81-85.

Courcelle, P., [1950] 1968, Recherches sur les Confessions de saint Augustin, De Boccard, Paris.

Courcelle, P. \& Courcelle, J., 1965, Iconographie de saint Augustin: Les cycles du XIV siècle, Études Augustiniennes, Paris.

Daniélou, J., 1964, The Theology of Jewish Christianity, Darton, Longman \& Todd/The Westminster Press, London/Philadelphia.

Ferguson, E., 2009, Baptism in the Early Church: History, theology, and liturgy in the first five centuries, Eerdmans, Grand Rapids/Cambridge.

Ferrari, L.C., 1975, 'Augustine's "nine years" as a Manichee', Augustiniana 25, 210 216

Frend, W.H.C., 1942, 'A note on the Berber background in the life of Augustine', Journal of Theological Studies 43, 188-191.

Frend, W.H.C., 1951, The Donatist Church, Oxford University Press, Oxford.

Gardner, I., 1996, Kellis literary texts, vol. 1, Oxbow Books, Oxford.

Gardner, I., 2007, Kellis literary texts, vol. 2, Oxbow Books, Oxford.

Gardner, I., Alcock, A. \& Funk, W.P. (eds.), 1999, Coptic documentary texts from Kellis, Oxbow Books, Oxford.

Gardner, I., \& Lieu, S.N.C. (eds.), 2004, Manichaean texts from the Roman Empire, Cambridge University Press, Cambridge. http://dx.doi.org/10.1017/ CBO9780511616891

Henrichs, A. \& Koenen, L., 1970, 'Ein griechischer Mani-Codex (P. Colon. inv. nr. 4780)', Zeitschrift für Papyrologie und Epigraphik 5, 97-216.

Jensen, R., 2011, Living water: Images, symbols, and settings of early Christian baptism, Brill, Leiden-Boston. http://dx.doi.org/10.1163/ej.9789004188983.i-306

Jensen, R., 2012, Baptismal imagery in early Christianity: Ritual, visual, and theological dimensions, Baker Academic, Grand Rapids. http://dx.doi.org/10.1163/ ej.9789004188983.i-306

Kelly, J.N.D., 1960, Early Christian creeds, Longmans, London.

Koenen, L. \& Römer, C., 1988, Der Kölner Mani-Kodex. Über das Werden seines Leibes. Kritische Edition aufgrund der von A. Henrichs und L. Koenen besorgten Erstedition, Westdeutscher Verlag, Opladen.

Ratzinger, J. [1965] 1967, Review of A. Adam, Lehrbuch der Dogmengeschichte I: Die Zeit der Alten Kirche, Jahrbuch für Antike und Christentum 10, 217-222.

Roberti, M.M. \& Paredi, A., 1974, I/ battistero ambrosiano di San Giovanni in Fonte, Fabbrica del Duomo di Milano, Milano.

Römer, C.A., 1994, Manis frühe Missionsreisen nach der Kölner Manibiographie. Tekstkritischer Kommentar und Erläuterungen zu pp. 121-192 des Kölner ManiKodex, Westdeutscher Verlag, Opladen.

Studer, B., 1993, Gratia Christi - Gratia Dei bei Augustinus von Hippo, Institutum Patristicum 'Augustinianum', Roma 1993.

Van Oort, J., 2002, Augustinus' Confessiones: Gnostische en christelijke spiritualiteit in een diepzinnig document, Brepols, Turnhout.

Van Oort, J., 2009a, 'Augustine, his sermons, and their significance', HTS Teologiese Studies/Theological Studies 65(1), Art. \#300, 10 pages, http://dx.doi.org/10.4102/ htsv6i1.300, viewed 28 November 2012, from http://www.hts.org.za/index.php/ HTS/article/view/300

Van Oort, J. 2009b 'Manichaeism: Its sources and influences on Western Christianity', Verbum et Ecclesia 30(2), 5 pages, Art. \#362, 5 pages, http://dx.doi.org/10.4102/ ve.v30i2.362, viewed 28 November 2012, from http://www.ve.org.za/index.php/ VE/article/view/362

Wilpert, G. 1931, 'Il più antico ritratto di S. Agostino', in Miscellanea Agostiniana, vol. 2: Studi Agostiniana, n.p., Tipografia Poliglotta Vaticana, Roma. 